In 1933 the activities of the Foréami were transferred to the region of the Kwango river. Apart from the Bas-Kwango and Moyen Wamba, where endemic sleeping sickness is serious, conditions in this district are favourable. There is no important endemic disease, and yet the inhabitants are sickly and of a very feeble constitution. Living on arid land, the native is contented with meagre crops and makes no serious effort to improve his conditions by extending his fields. This laziness suits his apathetic attitude and in complete fatalism he is satisfied to bear the consequences. In order to lead him to more normal life and to hasten his development, it was necessary to impose on him an effort of which he was not voluntarily capable and which aimed at providing him with sufficient food. The wretched hygienic conditions in which the native vegetates cannot be ameliorated unless his morale is improved and his means of subsistence increased. Helminthiasis, so widespread throughout the colony and only in exceptional cases dangerous to adult persons, finds here a propitious field for breeding; it is not exaggerated to regard it as an endemic disease. It must therefore be combated, but it was hopeless to expect any results as long as the population had not acquired sufficient resistance to benefit from treatment. The demographic condition of the region is a true picture of chronic malnutrition: a paradoxical and yet universal phenomenon among underfed populations is the fact that they are extremely prolific, but show an appalling rate of infant mortality. It is therefore to be hoped that the campaign started in 1935 , and which is being constantly intensified, will produce happy results. The political reorganization is stabilizing the social groups and is putting an end to laziness and fruitless quarrelling; the agricultural policy pursued with tenacity will increase the physical resistance and provide sufficient means of subsistence, while the development of medical assistance will diminish the mortality rate and contribute to a growth of the population. (Communicated by Professor N. De CleENe.)

\title{
L'Institut National pour l'Étude Agronomique du Congo Belge
}

DANs un pays à population limitée, où le travail minier prend une importance de plus en plus grande, le progrès agricole constitue l'élément stable du développement économique, et à ce titre l'activité de l'Institut National pour l'Étude Agronomique du Congo Belge (Inéac) acquiert un intérêt primordial. Créé pour promouvoir le développement scientifique de l'agriculture, il administre les stations de recherches dont la gestion lui est confiée par le Ministre des Colonies, organise des missions d'études agronomiques, engage des experts et des spécialistes et entreprend tous travaux quelconques se rapportant à son objet.

Cette multiple activité se manifeste dans le domaine des recherches de science pure et de science appliquée, tandis que les travaux de multiplication, de diffusion et de propagation ressortissent aux agents du Gouvernement. 
Il en résulte qu'une collaboration étroite entre les Services scientifiques de l'Inéac et le Service de l'Agriculture du Gouvernement est essentielle. Elle se réalise par l'échange des rapports et documents, par les stages qu'effectuent les agronomes du Gouvernement dans les stations de l'Inéac, par la fourniture de graines et de plants, par l'entreprise avec l'aide des agronomes de la Colonie d'essais régionaux en vue d'améliorer les cultures vivrières indigènes, par l'introduction de matériel sélectionné.

Outre cette collaboration directe, réalisée dans l'intérêt des colons et des indigènes, les stations de l'Inéac aident les sociétés et les planteurs avec leurs spécialistes, leurs laboratoires et leur matériel, sources précieuses de documentation et de consultation. A tous ceux qui expriment le désir, l'Inéac apporte son concours par l'établissement d'un programme d'essais culturaux à entreprendre dans leurs plantations et dont les résultats sont analysés et interprétés par ses spécialistes.

L'Inéac, comme les Services de la Colonie, constate que l'économie agricole $\mathrm{du}$ Congo repose sur un nombre trop restreint de produits. Cette limitation présente un danger pour la balance commerciale de la Colonie, ainsi que pour les planteurs dont l'activité ne comporte que quelques objets. Afin d'augmenter le nombre des produits agricoles d'exportation et d'améliorer ainsi les chances de réussite pour les planteurs, et en vue de répartir davantage les risques importants qu'entraîne la monoculture, l'Inéac met à l'essai et répand de nouvelles cultures, notamment le sisal, le pyrèthre, le quinquina, le thé, l'hévéa et les plantes fruitières. Il s'efforce en outre de mettre au point la préparation des produits et les méthodes culturales à recommander aux planteurs européens et indigènes. Ces méthodes, en ce qui concerne les autochtones, ne seront pas nécessairement les plus perfectionnées au point de vue technique. Il faut envisager le degré d'évolution de l'indigène ainsi que les possibilités d'exécution d'un programme éducatif qui tient compte des méthodes culturales traditionnelles.

Les publications de l'Inéac, conçues dans le but de porter à la connaissance des intéressés les principaux résultats de ses travaux, comprennent une série scientifique, une série technique et des ouvrages hors série, tels que les rapports annuels.

Dans la dernière catégorie vient de paraître un ouvrage, qui du point de vue du problème de l'alimentation présente un très haut intérêt pour les lecteurs d'Africa. En 1934 l'Inéac décida de créer parmi ses services une division d'agrologie et de subsidier une importante mission de prospection pédologique à travers la colonie. Le Professeur Bayens, qui en fut chargé, livre aujourd'hui à la publication ${ }^{I}$ les résultats de recherches poursuivies durant plusieurs années tant en Belgique qu'au Congo Belge. Si ces résultats sont importants au point de vue agronomique - il a su établir une échelle

' J. Bayens. Les Sols de l'A Arique centrale et spécialement du Congo Belge (Tome I, Le Bas Congo). 1938. Pp. 375 , cartes 9, figs. 3 1, photos 40, tableaux 50. 150 frs. 
de fertilité fondée sur des données analytiques qui ne manquera pas d'être utile aux planteurs et aux fonctionnaires chargés de trouver de nouvelles possibilités pour les cultures tropicales - ils ne le seront pas moins au point de vue de l'étude du régime alimentaire de l'indigène, étant donnée le vaste problème des rapports qui existent entre la nature chimique de la nourriture consommée et la nature chimique du sol. (Communication du Professeur N. de Cleene.)

\section{The Sherbro of Sierra Leone}

THE ethnography of West Africa is notoriously defective compared with that of East and South Africa. One of the worst gaps concerns our knowledge of the coastal cultures from Liberia northwards. It is safe to say that little of value has been added to the literature of this region since Westermann's Kpelle. The Hailey Survey cites only one recent publication referring to this region, a paper on one of the Sierra Leone tribes which appeared in this journal. Ethnologists will therefore welcome, as an earnest of further contributions to the ethnography of Sierra Leone, a brochure which has just appeared.

Published by the University Museum of the University of Pennsylvania, The Sherbro of Sierra Leone, by H. U. Hall, is a preliminary report of this museum's expedition to West Africa in 1937. Brief as it is-there are only Is pages of text, 17 pages of illustrations, and a map-this report will be of interest to every student of West African ethnography. The author, who spent about six months among the Sherbro or Bolom as they call themselves, gives us a summary of the main features of their culture. Much of his information covers familiar ground. It is none the less valuable to have such confirmatory observations.

Mr. Hall devoted attention mainly to Sherbro Island and to Shenge, where the old Sherbro culture is best preserved. Mende and Temne influences have begun to filter in. Normally, for instance, the ruling houses of the chiefdoms are exogamous matrilineal kinship groups (ram), but in some parts patrilineal descent is gaining the upper hand. The secret societiesPoro for men and Bundu for women-still flourish vigorously among the Sherbro, though Poro has lost its governmental functions. It can still, however, ban the overfishing of certain waters and impose penalties for gathering unripe nuts of communally owned palm trees. Poro also has charge of all burials. The ritual and esoteric features of these societies are briefly described. In some parts another society, Thoma, has replaced Poro and Bundu, and yet other secret societies principally concerned with 'medicines' flourish. Hobatoke, the Supreme Being, appears to be no more precisely conceived than elsewhere in West Africa, and the Earth as a mother goddess is a shadowy figure, says the author. The Sherbro notions of 'bad' and 'good' medicines and of witchcraft are equally characteristic of the Guinea Coast 